\title{
SPATIAL PATTERN IN PLANKTON COMMUNITIES
}




\title{
NATO CONFERENCE SERIES
}

\author{
I Ecology \\ II Systems Science \\ III Human Factors \\ IV Marine Sciences \\ V Air-Sea Interactions \\ VI Materials Science
}

\section{MARINE SCIENCES}

Volume 1 Marine Natural Products Chemistry edited by D. J. Faulkner and W. H. Fenical

Volume 2 Marine Organisms: Genetics, Ecology, and Evolution edited by Bruno Battaglia and John A. Beardmore

Volume 3 Spatial Pattern in Plankton Communities edited by John H. Steele 


\section{SPATIAL PATTERN IN PLANKTON COMMUNITIES}

Edited by John H. Steele

Woods Hole Oceanographic Institution

Woods Hole, Massachusetts

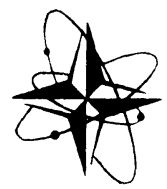

Springer Science+Business Media, LLC 


\section{Library of Congress Cataloging in Publication Data}

Nato Conference on Marine Biology, Erice, Italy, 1977.

Spatial pattern in plankton communities.

(NATO conference series: IV, Marine sciences; 3 )

Includes index.

1. Marine plankton - Congresses. 2. Vertical distribution (Aquatic biology) Congresses. 3. Marine ecology - Congresses. I. Steele, John H. II. Nato Special Program Panel on Marine Science. III. Title. IV. Series.

QH91.8 P5N37 $1977 \quad 574.9^{\prime} 2$

78-12017

ISBN 978-1-4899-2197-0

ISBN 978-1-4899-2197-0

ISBN 978-1-4899-2195-6 (eBook)

DOI 10.1007/978-1-4899-2195-6

Proceedings of the NATO Conference on Marine Biology

held at Erice, italy, November 13-21, 1977, and sponsored by the NATO

Special Program Panel on Marine Science

(c) Springer Science+Business Media New York 1978

Originally published by Plenum Press, New York in 1978

Softcover reprint of the hardcover 1st edition 1978

\section{All rights reserved}

No part of this book may be reproduced, stored in a retrieval system, or transmitted, in any form or by any means, electronic, mechanical, photocopying, microfilming, recording, or otherwise, without written permission from the Publisher 
FOREWORD

The planning for the conference held at Erice, Sicily, in November 1977 , began with discussions among oceanographers from several countries on the need to consider the special problems and the recent results in the study of plankton "patchiness." An approach to the Marine Sciences Panel of the NATO Science Committee resulted in a planning grant to determine the probable content and participation in such a meeting.

The planning group consisted of B. Battaglia (Padua), G.E.B. Kullenberg (Copenhagen), A. Okubo (New York), T. P1att (Halifax, Nova Scotia) and J. H. Steele (Aberdeen). The group met in Aberdeen, Scotland, in September 1976.

The proposal for a NATO School on the subject of "Spatial Pattern in Plankton Communities" was accepted by the Marine Science Panel and it was agreed that it be held at the Ettore Majorana Centre for Scientific Culture in Erice.

The Centre began in 1963 with an International School of Subnuclear Physics and has since developed to include courses in many other subjects which cover various fields of basic and applied research. The original aim of the Centre was to create, in Italy, a cultural forum of high scientific standard which would allow young research workers to appreciate problems currently of major interest in various fields of research. This is now attained by encouraging and promoting national and international meetings among specialists actively engaged in advanced disciplines, thus offering the younger scientists a unique opportunity to discuss with their more qualified colleagues the results of their investigations. Since these aims corresponded closely to those of the NATO School, we were happy to accept the kind invitation of Professor Zichichi, Director of the Centre. We wish to thank him and his colleagues at Erice for the hospitality enjoyed by all the participants. 
The Centre is sponsored by the Sicilian Regional Government, the Italian Ministry of Public Education, and the Ministry of Scientific and Technological Research. The various schools take place under the sponsorship and with some financial aid from these national agencies.

The Centre has its own journal: "Progress in Scientific Culture" whose articles have an interdisciplinary character. The Journal has published summaries of the lectures delivered during this NATO School.

The meeting at Erice provided valuable opportunities for interdisciplinary consideration of new and important questions in marine science. We hope this volume reflects the nature of these questions and the recent advances in this field. We are grateful to the NATO Science Committee for its support of the School.

Bruno Battaglia

John H. Steele 
CONTENTS

Some Comments on Plankton Patches

John H. Steele

Horizontal Dispersion and Critical Scales for Phytoplankton Patches

Akira okubo

Vertical Processes and the Vertical-Horizontal Coupling

G.E.B. KuZZenberg

Spectral Analysis of Spatial Structure in Phytoplankton Populations

Trevor Platt

Collection and Analysis of Underway Data and Related

Physical Measurements

Kenneth L. Denman and David L. Mackas

The Application of Particle Counting to an Understanding of the Small-Scale Distribution of Plankton

P. R. Pugh

The Application of Some Stochastic Processes to the Study of Plankton Patchiness

M.J.R. Fasham

Biological Effects of Vertical-Horizontal Interactions Geoffrey T. Evans

Mixing and Stabilization of Phytoplankton Distributions on the Northwest European Continental Shelf

$R$. D. Pingree

Patchiness in Subsurface Phytoplankton Populations on the Northwest European Continental Shelf

P. M. Holligan 
Spatial Heterogeneity in Closed Basins

Peter J. Richerson, Thomas M. Powell,

Mark R. Leigh-Abbott and John A. Coil

Patterns and Processes in the Time-Space Scales of

Plankton Distributions

L. R. Haury, J. A. McGowan and P. H. Wiebe

Growth and Surviva1 of First-Feeding Northern Anchovy

Larvae (Engraulis mordax) in Patches Containing

Different Proportions of Large and Small Prey

Reuben Lasker and James $R$. Zweifel

Spatial Distributions and Ecology of Pelagic Fish

J. W. Homwood and D. H. Cushing

Patches, Movements, and Population Dynamics in

Ecological Systems: A Terrestrial Perspective WiZliam C. Clark, Dixon D. Jones and C. S. HolZing

Pattern Formation in Ecological Communities

Simon A. Levin

Index 


\section{PARTICIPANTS}

\author{
G. Andreoli, Italy \\ M. Azzali, Italy \\ B. Battaglia, Italy \\ R. Benzi, Italy \\ C. M. Boyd, Canada \\ P. Chryssovergi, Greece \\ W. C. Clark, Canada \\ J. M. Colebrook, U.K. \\ B. Coste, France \\ M. E. Cunha, Portugal \\ K. L. Denman, Canada \\ D. M. Dubois, Belgium \\ R. C. Dugdale, U.S.A. \\ M. Van Der Eijk, Netherlands \\ M. Estrada, Spain \\ G. T. Evans, U.K. \\ M.J.R. Fasham, U.K. \\ P. Franco, Italy \\ S. Gaiardi, Italy \\ L. Guglielmo, Italy \\ G. Harris, Canada \\ P. M. Holligan, U.K. \\ J. W. Horwood, U.K. \\ L. Ignatiades, Greece \\ G.E.B. Kullenberg, Germany \\ R. Lasker, U.S.A. \\ S. A. Levin, U.S.A. \\ A. R. Longhurst, U.K. \\ D. Mackas, Canada \\ G. Magazzu, Italy
}

S. Mater, Turkey

J. A. McGowan, U.S.A.

M. Moraitou-Apostolopoulou, Greece

P. Nival, France

A. Okubo, U.S.A.

T. Ongan, Turkey

I. Oze1, Turkey

V. Parisi, Italy

R. D. Pingree, U.K.

T. Powe11, U.S.A.

P. R. Pugh, U.K.

G. Radach, Germany

P. J. Richerson, U.S.A.

S. E. Salusti, Italy

A. P. dos Santos Matos, Portugal

F. Schott, Germany

W. Silvert, Canada

N. Staresinic, U.S.A.

J. H. Steele, U.S.A.

K. H. Szekielda, Germany

S. Tilseth, Norway

G. M. de Vasconcelos, Portugal

J. J. Walsh, U.S.A.

G. White III, Canada

J. D. Woods, Germany

J. S. Wroblewski, Canada

C. S. Yentsch, U.S.A.

D. Zafiropoulos, Greece

M. Zaru11, Canada

B. Zeitzschel, Germany 